\title{
Land Inequality, Education, and Marriage: Empirical Evidence from Nineteenth-Century Prussia
}

\author{
Francesco Cinnirella \\ Erik Hornung
}

CESIFO WORKING PAPER NO. 6072

CATEGORY 5: ECONOMICS OF EDUCATION

SEPTEMBER 2016

An electronic version of the paper may be downloaded

- from the SSRN website:

- from the RePEc website:

wWw.SSRN.com

Www.RePEc.org

- from the CESifo website:

www.CESifo-group.org/wp 


\title{
Land Inequality, Education, and Marriage: Empirical Evidence from Nineteenth-Century Prussia
}

\begin{abstract}
In this study we review the literature on the relationship between landownership inequality and the accumulation of human capital in historical perspective. Furthermore we provide new evidence on the relationship between landownership inequality and marriage patterns at the county level in nineteenth-century Prussia. Formally the landed elite could have inuenced not only the labor relations with the peasants but also their marriage decisions. Using cross-sectional as well as panel analysis we find no evidence that noble landowners directly affected marriage rates. Instead we find a robust negative association between average formal education and the share of married women. This finding is in line with recent theoretical and empirical literature on the role of gender specific human capital in the demographic transition.
\end{abstract}

JEL-Codes: O430, Q150, I250, J120, N330.

Keywords: land inequality, education, marriage, Prussian economic history.

Francesco Cinnirella Ifo Institute - Leibniz Institute for Economic Research at the University of Munich Poschingerstrasse 5 Germany-81679 Munich cinnirella@ifo.de
Erik Hornung

University of Bayreuth Department of Law and Economics Universitaetsstr. 30 Germany-95447 Bayreuth erik.hornung@uni-bayreuth.de

August 26, 2016

Chapter prepared for the CESifo/MIT Book "Demographic Change and Long-Run Development” edited by Matteo Cervellati and Uwe Sunde. 


\section{Introduction}

A vast literature documents the effects of economic and political inequality on development and growth. A significant part of this literature focuses on the political economy channel and argues about the importance of the initial distribution of wealth for the distribution of political power. According to this literature, the initial existence (or formation) of an economic elite will lead to the concentration of political power in the hands of few which will in turn lead to the introduction of political institutions designed to sustain inequality (see Acemoglu, Johnson, and Robinson, 2001, 2002; Engerman and Sokoloff, 1997; Sokoloff and Engerman, 2000). Such societies fail to adopt redistributive policies that allow for an optimal investment in physical and human capital (see Alesina and Rodrik, 1994; Persson and Tabellini, 1994). Therefore, in the long-run, elite-based societies will not develop institutions conducive to sustainable economic growth and thus will not match the income levels of economies with lower initial levels of inequality.

Elites generally oppose redistribution using their political power to block the extension of voting rights or the expansion of school financing for mass education (see Acemoglu and Robinson, 2006; Gallego, 2010; Galor, Moav, and Vollrath, 2009; Go and Lindert, 2010; Naidu, 2012; Ramcharan, 2010). In a recent article, Cinnirella and Hornung (2016) propose an alternative mechanism based on the labor relations between the (landed) elite and the masses. Due to the decentralized character of public schooling in Prussia (Lindert, 2004), elites were not in the position to delay the expansion of mass schooling through the political channel. Yet, due to the prevailing institutions of the feudal system, the nobility exercised a direct authority over policing and jurisdiction and was patron over churches and schools in rural villages. Similarly, labor relations characterized by the coercion of labor lingered on way into the nineteenth century. Thus, their position of power allowed them to directly interfere with the education decisions of the peasantry.

Cinnirella and Hornung (2016) provide evidence for such exercise of authority by documenting the relationship between landownership concentration and peasants' investments in education. They show that the regional concentration of noble large landowners is associated with lower enrollment rates in mass primary schooling. Furthermore, due to the introduction of agricultural reforms that eroded the authority of noble landowners, peasants gradually emancipated and increasingly enrolled in primary schools. Throughout the nineteenth century, the negative effect of the nobility on education vanishes. Further findings indicate that the nobility did not limit the provision of public schooling by restricting the supply of teachers and schools. The nobility rather restricted the demand for schooling through the coercion of labor services that prevailed even after serfdom was formally ended. 
This chapter revisits the previous findings of a detrimental effect of landownership concentration on enrollment rates in nineteenth century Prussia. It further proceeds to analyze a second aspect of possible interference of the landed elite with peasant's individual life - the decision to get married. Until the agricultural reforms of the beginning of the nineteenth century, peasants were not allowed to get married without the consent of the noble landowner. This might have affected marriage patterns across Prussia in an unknown direction. It is likely that the landed elite favored the formation of families to increase the labor force bounded to land. On the other hand, the landed elite likely was interested in preserving a sufficient number of unmarried servants. Since celibacy and age at marriage are the most important determinants of fertility (Hajnal, 1965; Voigtländer and Voth, 2013), the potential relationship between land inequality and marriage is of great interest.

We expand the unique dataset compiled by Cinnirella and Hornung (2016) to include information about female marriage rates and sex ratios so as to estimate the relationship of interest throughout the nineteenth century. This dataset further includes the distribution of landownership by size, primary school enrollment rates, and a range of development indicators (see also Becker et al., 2014). Using cross-sectional as well as panel analysis with county-fixed effects, we find no systematic evidence for the hypothesis that noble landowners directly interfered with the marriage decision.

However, we find a robust negative association of education with the share of married women in a panel analysis with county and time-fixed effects. Thus, in regions where the authority of the landed nobility decreased and the demand for education increased, a smaller share of women got married. This finding is in line with the recent theoretical and empirical literature on the role of gender specific human capital in the demographic transition (de la Croix and Donckt, 2010; Galor and Weil, 1996; Iyigun and Walsh, 2007; Lagerlöf, 2003). During the process of industrialization and accumulation of physical capital, occupations became increasingly human capital intensive. Educated women entering the industrial labor force earned higher wages and gained independence of male support. In this way, (female) investments in education changed the marriage pattern by postponing the age of marriage, increasing celibacy, and consequently reducing fertility over the course of the nineteenth century. By analyzing marriage patterns, this chapter provides preliminary evidence for an additional mechanism through which education could have affected the demographic transition in Europe.

The chapter is structured as follows: in Section 2 we discuss some theoretical aspects of human capital formation and marriage patterns; Section 3 reviews the empirical literature on inequality and education; Section 4 provides a historical background regarding the Prussian agrarian reforms, school financing and marriage patterns; Section 5 describes the 
data; Section 6 presents the empirical analysis of the relationship between landownership concentration and education; Section 7 presents preliminary evidence on the association of landownership and education with marriage; Section 8 concludes.

\section{Theory}

\subsection{Accumulation of Human Capital}

Recent theoretical growth models assume a complementarity between physical and human capital to explain the increasing role of education in the second industrial revolution. The accumulation of physical capital in the process of development increases the importance of skills and human capital in production. This creates a conflict of interest between owners of capital and land, factors of production that are characterized by different complementarities with human capital (Galor and Moav, 2006).

Galor, Moav, and Vollrath (2009) provide a theoretical framework which links landownership inequality with investments in public education. The model suggests that inequality in the distribution of landownership adversely affects the emergence of human-capital promoting institutions, thus affecting the transition process towards an industrial economy and the path to modern economic growth. Because of complementarities between physical capital and skills, capitalists strive for an educated labor force and support policies that promote public education. Conversely, the landowning elite is interested in reducing the mobility of the rural labor force and thus opposes policies favoring mass education. Due to a lower degree of complementarity between human capital and land, a rise in the level of education would push the rural labor force out of agriculture thus reducing the return to land because of labour migration and higher agricultural wages. Large landowners have therefore fewer incentives to support public schooling for the masses.

If the political process is dominated by large landowners they might prevent the implementation of public policies such as the expansion of public education. In fact, the model proposed by Galor, Moav, and Vollrath (2009) suggests that the negative impact of the landed elite on education increases with the concentration of landownership. This is a sensible prediction as there is substantial historical evidence supporting the notion that in pre-industrial Europe political power increased proportionally with the possession of land. The model also predicts that the landowners will stop opposing public policies in favor of education to the point when their stakes in the industrialization process are large enough to reap the benefits of a higher level of skills.

The negative impact of landownership concentration on education also diminishes if the political power of the landed elite is eroded by institutional reforms. Galor and Moav (2006) suggest that capital-skill complementarity and the resulting conflict of interest 
between industrialists and agriculturalists in the provision of public education planted the seeds for the demise of the class-structure. Therefore a shift in the balance of power towards the owners of physical capital and the passing of land reforms and education reforms can be interpreted in the light of such a theory. In this vein, Cinnirella and Hornung (2016) show that agricultural reforms and the gradual emancipation of the peasants during the nineteenth century in Prussia changed the underlying relationship between landownership inequality and education.

Lindert (2004) describes the factors which foster or retard the expansion primary and secondary education across the world. According to Lindert, elite self-interest, democracy, and decentralization are the crucial factors which define the success or failure of public policies on education. Similar to Galor and Moav (2006) and Galor, Moav, and Vollrath (2009), Lindert argues that powerful landed elites, such as the Tories in England, opposed the spread of education to the lower strata of the society (Lindert, 2004, p. 100). However, regarding the role of capitalists, Lindert considers the social-control hypothesis rather than the capital-skill complementarity. According to the former hypothesis, industrialists favor a centralized and mandatory schools system to create a disciplined and obedient labor force, important for the factory system (Lindert, 2004, p. 101). Both hypothesis, though based on different premises, predict a positive relationship between industrial development and the spread of mandatory primary education.

According to Lindert, the emergence of mass primary education depends strongly on the level of decentralization of the political process which leads to the provision of public schooling. In particular, Lindert argues that local control of school finances could exert a positive effect on primary schooling in the context of early development. Decentralization of government allows to vote for local taxes and schools. Therefore the early leaders in education were those countries in which local governments were free to choose their optimal level of (tax-based) public expenditure on education. Lindert thus reinterprets the nineteenth-century success of German (Prussian) education, ascribing the high level of education to the high level of political decentralization of educational policy. In his view, the German educational leadership during the nineteenth century was the result of a localized bottom up process rather than of a process controlled by the political elite in Berlin (Lindert, 2004, p. 115).

\subsection{Human Capital, Fertility, and Marriage}

In the second part of this chapter we investigate how landownership concentration is related to female marriage rates. To our knowledge, economic theory has not directly linked land inequality to female marriage rates. Since the political channel cannot play a role in individual marriages decisions, such a connection seems debatable. However, 
Cinnirella and Hornung (2016) argue that land inequality determined the individual demand for schooling. Here we discuss whether land inequality might also play a role in determining individual marriage decisions. This section presents a range of theories that explain marriage patterns.

One might argue that both land inequality and marriage rates are driven by some underlying mechanism, such as changes in the land-labor ratio. Late age at marriage and a relatively high celibacy rate define the so-called European Marriage Pattern (henceforth EMP) (Hajnal, 1965). The EMP emerged as early as the 14th century in Western Europe (west of a line from St Petersburg to Trieste) and contributed to limit fertility by avoiding 25-40\% of all possible births. Voigtländer and Voth (2013) argue that the Black Death played a crucial role in the rise of the EMP. According to their theory, the Black-Death raised the land-labor ratio favoring animal husbandry, a sector in which women had a comparative advantage. Thus, after the Black Death female employment opportunities in husbandry improved which, in turn, provided an incentive to remain celibate as pregnancy and marriage resulted in termination of employment (Voigtländer and Voth, 2013). The distinct cleavage between the EMP and the Eastern EMP alongside the so-called Hajnal line resembles the European border between regions that abolished serfdom comparatively early and regions that embraced the second serfdom - both divergences arose after the Black Death epidemics of the fourteenth century. Similar to the development of the EMP, the Black-Death raised the land-labor ratio and changed the bargaining power between the serfs and the nobility leading to the disappearance of serfdom in western Europe and to an intensification of serfdom in eastern Europe. As exemplified with the consequences of the Black Death during the 14th century, changes in the land-labor ratio might affect changes in serfdom institutions and marriage patterns and therefore qualify for the underlying mechanism that links landownership concentration and female marriage rates.

Alternative explanations for the EMP include De Moor and Van Zanden (2010), who argue that the pattern emerged as a result of the preaching of the Catholic Church promoting marriage based on consensus. In addition they also consider access to urban labor markets and the system of intergenerational transfers to explain the emergence of the EMP. Foreman-Peck (2011) develops a model which relates the EMP to investments in human capital and subsequent growth. In his model, later marriage raised the level of education of women as they had more time to acquire human capital before child bearing and rearing which in turn translated into higher income levels. Based on a review of the historical demography literature, Dennison and Ogilvie (2014) argue that there is no evidence of a relationship between the characteristics of the European Marriage Pattern and economic growth. 
In this chapter we will present evidence for the lack of a direct link between landownership concentration and female marriage rates, but rather a significant negative association between the share of marriage rates and investments in education. The demand for skilled labor during the Industrial Revolution of the nineteenth century increased the female labor force participation (henceforth FLFP) and thus lowered female marriage rates. Galor and Weil (1996) model the relationship between the gender wage gap, fertility, and modern economic growth. In their model an increase in capital per worker raises the relative wage of women as female labor is more complementary to capital than male labor. An increase in the female relative wage raises the opportunity cost of children by proportionally more than the couple's full income, thus lowering fertility. A crucial element of their theory is that an increase in the capital intensity of the economy raises the relative wages of women. This is based on the notion that in the process of development the economy rewards those characteristics more in which women have a comparative advantage.

In the spirit of Unified Growth Theory (Galor, 2011), Diebolt and Perrin (2013a,b) propose a model which emphasizes the role of women in the development process. In particular, they stress the role of gender equality in education and occupation as a crucial determinant of the demographic transition. According to their theory, once technological progress is sufficiently high and gender equality reaches a given threshold, women will enjoy the benefits of high returns to education. Higher investments in education by women will increase their bargaining power within the household which, in turn, will allow them to enter the labor market. Investing in education will increase the opportunity cost of children for women and they will have fewer children. The role of women in the model thus offers an alternative explanation of the demographic transition and can account for the reversal in the relationship between income and population growth.

We will provide evidence that landownership concentration in nineteenth-century Prussia is not directly related to the share of married women. Yet, we will provide robust evidence that increases in enrollment rates over the century are negatively associated with marriage rates. ${ }^{1}$ This preliminary result is consistent with the theory that higher levels of development increased the returns to education and the employment opportunities for women who, in turn, married later or to a lesser extent, thus increasing the celibacy rate. These preliminary findings are broadly consistent with the theories on gender equality and growth of de la Croix and Donckt (2010); Diebolt and Perrin (2013b); Galor and Weil (1996); Iyigun and Walsh (2007); and Lagerlöf (2003).

\footnotetext{
${ }^{1}$ Unfortunately we cannot separate the effect of female from male enrollment rates as the two variables are highly correlated. In addition enrollment rates by gender are not available for all time periods.
} 


\section{Literature Review}

There is a large empirical literature which analyzes the economic consequences of inequality for human capital. One strand of literature focuses on redistribution. Alesina and Rodrik (1994) and Persson and Tabellini (1994) hypothesize that in a more egalitarian society, taxation of physical capital and of human capital is lower, enhancing economic growth. Ramcharan (2010) studies the relationship between land inequality and education expenditure in the United States for the period 1890-1930. The paper shows that land inequality is negatively associated with redistribution and therefore with less expenditure on education. The issue of causality is addressed by using geographic variables such as surface elevation, rainfall, and crop choice to identify exogenous variation in land inequality. ${ }^{2}$

The theoretical model of Galor, Moav, and Vollrath (2009) focuses on the low complementarity between agriculture and human capital and predicts an adverse effect of the concentration of landownership on education expenditure. The authors test this prediction for the United States for the period 1900-1940 using variation in the distribution of landownership and educational expenditure across states and over time. Indeed, they find that land inequality has a negative impact on education expenditures. They address causality through an instrumental variable approach. In particular, they identify variation in landownership inequality through the interaction between nationwide changes in the relative price of agricultural crops that are associated with economies of scale, and variation in climatic characteristics across states. Kourtellos, Stylianou, and Ming Tan (2013), by employing duration models in a sample of 53 countries, find that higher levels of land inequality delay the expansion of schooling. Their findings are consistent with the theory proposed by Galor, Moav, and Vollrath (2009).

Go and Lindert (2010) stress the political-economy channel in the provision of public education in U.S. In particular, in explaining the gap in enrollment rates between the North and the South in 1850, they point to local governments having more autonomy and the population having a more equally distributed political voice in the North. Among other things, they find that extending the voting power to lower-income groups raises the taxes paid for schooling and thus the primary-school enrollment rates. Vollrath (2013) finds that landownership inequality predicts taxes for local school funding at the U.S. county level in 1890.

The so-called Engerman and Sokoloff hypothesis (Engerman and Sokoloff, 1997) suggests that initial factor endowments create differences in economic inequality which, in turn, generates "low quality" institutions which induce low investments in human capital

\footnotetext{
${ }^{2}$ For the long-run effects of property rights on health and educational outcomes, the reader is referred to Banerjee and Iyer (2005).
} 
and cause differential development paths. Engerman and Sokoloff argue that the geography of Latin America, characterized by large economies of scale, led to the use of slave labor which brought about high levels of inequality. In contrast, the natural endowments of North America led to smaller-scale family farms, generating less inequality and thus promoting the growth of a large middle class. Easterly (2007) tests the hypothesis of Engerman and Sokoloff and finds that inequality has a significant negative long-run effect on per capita income (in 2002), institutions, and secondary school enrollment rates for the period 1998-2002 (Easterly, 2007, p. 766, Table 4). Easterly uses the soil suitability for the cultivation of sugar versus wheat to identify variation in inequality. Nunn (2008), when testing the Engerman and Sokoloff hypothesis finds that slavery is associated with underdevlopment. Yet his analysis suggests that the detrimental effect of slavery on development does not work through its impact on initial economic inequality. In an attempt to reject geographic determinism, Clark and Gray (2014) argue that large-scale farming in south-east England in the nineteenth century is not associated with lower levels of education measured in terms of literacy rates.

Finally, another strand of literature considers variations in the levels of human capital as an outcome of institutions (Acemoglu, Johnson, and Robinson, 2001, 2002; Acemoglu, Gallego, and Robinson, 2014). According to this literature, countries which developed "extractive" institutions are generally characterized by the concentration of political power in the hands of a small elite and by a vast majority of population without effective property rights. On the contrary, countries with more "inclusive" political institutions tend to have economic institutions which are more conducive to economic growth. By estimating the correlation between schooling and literacy rates with inequality in political power, Mariscal and Sokoloff (2000) show to what extent the extension of the franchise in Latin America increased schooling. The relationship between the extension of the franchise and schooling has also been analyzed theoretically in Acemoglu and Robinson (2000). Gallego (2010) explores the role of historical variables and political institutions to explain differences in schooling in former colonies. He argues that the degree of democratization positively affects primary education, whereas decentralization of political power is more related to differences in higher levels of schooling, such as secondary and higher education. Dell (2010), instead, analyzes the persistent effect of coercive labor institutions on human capital. 


\section{Historical Background}

\subsection{Noble Authority and Agricultural Reforms}

A distinguishing feature of the old Prussia and the western territory gained at the Congress of Vienna is the organization of agriculture. ${ }^{3}$ The river Elbe is the geographical reference point generally used to distinguish the two agricultural regimes: ${ }^{4}$ the dominant regime in the western provinces was Grundherrschaft and the dominant regime in the eastern province was Gutswirtschaft. In the western system of Grundherrschaft the nobility owned the land but did not participate in its cultivation and relied on cash rents paid by the tenants. In the Eastelbian system of Gutswirtschaft noble lords operated large parts of the estate and relied on labor services provided by serf peasants. Due the close personal relationship between noble landowners and peasants in the Eastelbian system, the exertion of noble authority and legal control was more prevalent than in the western system.

Control and authority of noble landlords over the peasantry included policing, jurisdiction (Patrimonialgerichtsbarkeit), tax collection, and the appointment of priest and schoolteachers (Patronatsrecht) (Bowman, 1980; Eddie, 2013). As patron of the estate, the noble landowner was responsible for the education and religiosity of the individuals. He appointed the schoolmaster and provided the instructions under which the school was to operate. In some cases estate owners even prescribed the content of the school curriculum (Berdahl, 1988, p. 55-63). ${ }^{5}$ From the age of 14, children could be drafted for compulsory domestic service (Gesindezwangsdienst) at the manor. Furthermore, the noble landowner had the ability and power to interfere with a range of individual decisions such as marriage, land transfer, conflict resolution, and migration. Ogilvie (2005) argues that noble intervention in individual decisions was highly effective since it needed to be exercised rarely. In return for their services, landowners had the obligation to protect their subjects and to provide relief in case of need such as accidents and bad harvests. Benefits for the serfs further included the rights of common, including the grazing rights to the commons, and might include the right to fish and cutting wood.

Noble authority and personal subjection started to resolve towards the end of the eighteenth century and peasant emancipation gained much momentum after the agricultural reforms of the early nineteenth century. The Prussian King aimed to inspire nobles by abolishing serfdom on the royal domains in 1799. After losing the war against the

\footnotetext{
${ }^{3}$ at the Congress of Vienna Prussia received two fifths of Saxony, Swedish Pomerania the Grand Duchy of Posen, Danzig, and the provinces of Rhineland and Westphalia.

${ }^{4}$ The Elbe does not present a clear discontinuity between the regimes and the transition between the systems was gradual (Rosenberg, 1944).

${ }^{5}$ The appointment of the schoolteacher for the estate-school remained within the authority of the estate owner even around 1900 (Neugebauer, 1992, p.684). Note that teachers might be selected by noble landowners; the payment of teacher salaries however fell on the entire community.
} 
French Revolutionary Army, the Prussian Reforms (Stein-Hardenberg Reforms) enacted by a small group of enlightened bureaucrats introduced a series of changes of agricultural institutions. The "Edict of October 1807" abolished the legal institution of servitude starting from November 11 (St. Martin's Day) 1810. In 1811 another edict clarified how former serfs could acquire property and become owners of their plots. Due to the opposition of the nobility, in 1816 the scope of the edict was restricted and excluded peasants on small plots (those that did not use drought animals to cultivate land). Consequently, the nobility maintained a de facto authority over two thirds of the peasantry which continued to provide mandatory labor services (Harnisch, 1984). The legal process at the local level remained under the control of the landed nobility until the constitution of 1849 changed the system of noble mediation. Only from 1850 all peasants gained complete legal emancipation and were able to discard and redeem labor services (Pierenkemper and Tilly, 2004; Bowman, 1980).

In the western Prussian regions of Rhineland and Westphalia most noble prerogatives were abolished during the French occupation period between 1794 and 1814. Serfdom was abolished de jure, in the Rhineland in 1805 and in Westphalia in 1808. However, Westphalian nobles tried to block many of the changes introduced by the Napoleonic Code. While the Code Napoleon remained effective after 1815 in the areas left of the river Rhine, other areas formally (re-)established Prussian law (Allgemeines Landrecht). ${ }^{6}$

\subsection{Education and School Financing}

According to Schleunes (1979, p. 317), the war against France triggered a "decade of feverish activity" leading to a first surge in primary schooling (see Figure 1). Prussia is well-known to be the world leader in education during the nineteenth century, especially in primary education. The roots of mass schooling can be traced back to Martin Luther's call for setting up Protestant schools in rural areas (see Becker and Woessmann, 2009). Also, the Prussian King pushed for compulsory education first in 1717 and again in 1763. However, the state did not provide financing and the King's edicts were rather attempts to persuade the landed nobility to provide education at their own expenses (Lindert, 2003, 2004). Thus, it took until the defeat of the Prussian Army by the French Empire in 1806 when mass education moved into the public focus in Prussia.

According to Lindert (2004) schooling had never been of special national interest and was left to the local leaders. He interprets Prussian educational history as a bottomup rather than a top-down story. In fact, resources for school funding derived from a range of local sources. A large share of the expenses was provided by assets held by the

\footnotetext{
${ }^{6}$ For more details about the regional adoption of reforms you are referred to Acemoglu et al. (2011) and the corresponding online appendix.
} 
local school such as real estate, entitlements or capital rents. Similarly, teacher salaries were derived from a range of sources including tuition fees (17\%), school assets (11\%), local school taxes $(60 \%)$, and state funds $(12 \%){ }^{7}$ So-called schooling societies, bodies of the municipality received funds from the school tax. Taxpayers were the heads of each household (excluding noble landowners) proportional to their wealth and income, independent of their religious denomination and number of children.

Tuition fees were usually charged if society funds were insufficient. Noble landowners were only to contribute to school financing if local families could not afford to pay for schooling (Kuhlemann, 1991, p. 181). In addition, poor school districts received financial support from the State (Königliches Statistisches Bureau in Berlin, 1889, pp. 58-59). Tuition fees were abolished in 1888 and the exemption of noble estate owners from school financing and school taxes was abolished in 1906.

The Prussian Statistical Office provides comparative information on school financing for the period 1861-1886. Table 1 presents an overview of total per-capita school funds at the province level. Similar to Lindert (2003, 2004), we find that Eastern provinces had relatively lower school funds compared to Western provinces. For example, primary school funds amounted to about 1.4 Marks per capita in East- and Westprussia in 1861, ${ }^{8}$ whereas it amounted to 1.8 Marks in the Western province of Rhineland. However, it is important to note that this difference may reflect differentials in the cost of living. In fact, if we deflate school funds per capita with rye prices in 1861, funds in the provinces of East- and Westprussia are 10 and 14\% higher than in Rhineland, respectively.

Consistent with the finding that deflated funds did not systematically differ across Prussia, Cinnirella and Hornung (2016) observe no appreciable difference between the East and the West when looking at the number of schools and teachers per child at school-age. A further subdivision of the sources of school funding in Table 2 shows that, throughout the period considered, less developed Eastern provinces such as Eastprussia, Westprussia, and Poznan benefited to a larger extent from State contributions than the Western provinces of Westphalia and Rhineland. On the contrary, school funds in Eastern provinces relied to a much lesser extent on tuition fees. In 1861, in the provinces of Rhineland and Westphalia, tuition fees accounted for 24 and $27 \%$ of the total school funds, respectively; instead, in East- and Westprussia tuition fees accounted for only 11 and $13 \%$ of the total school funds, respectively.

Therefore, the lower (nominal) level of financial support in the rural eastern areas arguably did neither impact the availability of schools nor that of teachers. ${ }^{9}$ Supply of

\footnotetext{
${ }^{7}$ Shares correspond to the distribution of funds across sources as of 1886 (Königliches Statistisches Bureau in Berlin, 1889, p. 84).

${ }^{8}$ Note that both provinces of East- and Westprussia belong to the East-Elbe part of Prussia.

${ }^{9}$ We cannot exclude that it affected their quality.
} 
education was not restrained in the Eastern regions. As we will argue in this chapter, it was the noble authority that affected the private demand for education, which explains the delay in educational attainment of the agricultural Eastern regions of Prussia to a large extent.

\subsection{Marriage Patterns}

In Prussia, the decision to marry was effectively influenced by institutions prevailing from the feudal system and the church, as well as individual incomes. The marriage pattern in Catholic regions is distinctively different from Protestant regions; with a higher propensity to be married in Protestant regions. Feudal institutions provided that marriage was allowed only with the consent of the noble landlord. Marriage decision were also determined by labor relations and therefore not possible for domestic workers and servants (Gesinde) usually accommodated within the household of their employer. ${ }^{10}$ Consequently, the serf institution of compulsory domestic service for the nobility might have led to a lower share of marriages. ${ }^{11}$ The share of females that provided domestic service to the nobility was $1.8 \%$ in the Prussia east of the Elbe and $0.8 \%$ in the Prussia west of the Elbe in 1816. This pattern seems to remain relatively stable over time; in 1849 it was $2.0 \%$ in the East and $1.0 \%$ in the West. Therefore, variation in the concentration of noble landowners across Prussia might affect differential marriage patterns.

According to Eddie (2013), noble landowners were obligated to support their peasants in lean times. Since female peasants from outside of the village became the concern of the landowners upon marriage, nobles might have paid attention to the economic circumstances of the marriage. Yet, Ogilvie (2005, p.98) finds that noble lords rarely interfered with serf marriages. Of the 111 requests for permission to marry that were denied and brought to the noble court on the Bohemian estate of Friedland only $18 \%$ were ultimately refused. The reason to refuse the request was usually that the female serf was subject to another lord and this created incentives for the male serf to run away. This indicates that the nobility might have decreased marriage rates. On the other hand, individual incomes might affect marriage decisions. Upon marriage, peasants were expected to establish a new household on the estate of the lord. Running an independent household or a farm was considered infeasible without a wife. Adult children of serfs would often wait to get married until they inherited the land of their parents to have a sufficient income. This might postpone marriage to later stages in life. According to (Ogilvie, 2005) the nobility might thus have ordered male peasants to marry and thus

\footnotetext{
${ }^{10}$ Similarly, apprentices living in the household of their masters were not allowed to marry.

${ }^{11}$ The compulsion to provide domestic service to the nobility was abolished with serfdom institutions in 1810 . Since the nobility still required servants, a large proportion of the population provided domestic services by choice and against wage payment.
} 
increased marriage rates. With the agricultural reforms of 1807, the power and authority of noble landowners over the peasant population eroded. Fees which had to be paid to the noble landowner upon marriage were abolished. Peasants were able to chose to get married without the consent of the landowner. This might have affected the propensity to get married in an unknown direction.

During the nineteenth century, the Industrial Revolution created a range of new employment opportunities that affected individual incomes and provided independence from the necessity to inherit land. Consequently, the share of married women across Prussia might have increased. However, the effect would be reversed if an increasing number of women entered the industrial labor force and earned an independent income. According to Wrigley (2006), women in regions with a large textile industry postponed marriage much more than in regions with a large mining and metals industry. Wrigley (2006) assumes that part of the effect operates through sex ratios, leading to a high ratio of women to men in textile regions and a high ratio of men to women in mining regions; resulting in a higher share of the population having trouble to find an adequate spouse.

Data on marriage rates and female labor force participation across Prussian counties in 1882 support the hypothesis that employment opportunities for women are associated with a lower propensity to marry. In Figure 2 we plot the share of married women in 1885 against female labor force participation in 1882. The two variables are significantly negatively correlated. Further below we will show that landownership concentration is, in fact, not related to marriage rates, whereas enrollment rates show a significant robust negative relationship with marriage rates.

\section{Data}

Our analysis of the relationship between landownership, education, and marriage rates is based on county-level data from nineteenth-century Prussia. Our data set includes data from five time-periods $(1816,1849,1864,1886$, and 1896) collected from various sources published on behalf of the Royal Prussian Statistical Bureau in Berlin. This section describes those variables that are particularly important for this project: information on land ownership structure by size, enrollment rates in primary schools, and the marital status and age structure of the female population. Control variables such as population size, urbanization, religious denomination, and industrial structure are also included in the regression analysis. ${ }^{12}$

The main variable of interest, public primary school enrollment rates refer to school attendance of the 6 to 14 years-old. Consistent with the definition of mandatory schooling

\footnotetext{
${ }^{12}$ Much of the data are stored in the ifo Prussian Economic History Database (iPEHD). For more details on variables and sources of the iPEHD you are referred to Becker et al. (2014) and Cinnirella and Hornung (2016).
} 
at the time, we consider both elementary schools (Elementarschulen) and middle schools (Mittelschulen) as primary schools. ${ }^{13}$

For the analysis of marriage patterns, we combine a range of data from different population censuses. We define the share of married women as the total number of married women over the total number of women older than 15 years. It is important to note that we measure marriage rates at the same time or close to all other explanatory variables in our five cross sections. Unfortunately, county-level information on married women is unavailable during the period 1850-1870. For the cross section labelled 1864, we thus construct the share of married women using data for 1871, while we include enrollment rates for 1864, and landownership concentration for 1858 .

The Prussian censuses report the number of landholdings per county and classify them into size bins. The first full census in 1816 classifies land holdings in three groups: properties or leasehold estates of up to 15 Prussian Morgen (henceforth PM), from 15 to $300 \mathrm{PM}$, and more than $300 \mathrm{PM}^{14}$ This categorization reflects the contemporary agricultural structure of farming. Farmers with less than 15 PM usually required some additional form of non-farming income. Landholdings between 15 and 300 PM were generally large enough for the subsistence of a family, whereas farms with more than 300 PM were usually cultivated by paid laborers and coerced labor, while the owner was not expected to perform any manual work (Harnisch, 1984). The 1849 census classifies landownership in 5 groups: up to 5 PM, 5 to 30 PM, 30 to 300 PM, 300 to 600 PM, and more than 600 PM. The agricultural census in 1855 follows the same structure. From 1882 onwards the census considers only arable land and the unit of measurement changes from Prussian Morgen to hectare (ha). In particular, the occupation census in 1882 classifies farms in six groups: farms with arable land up to 1 ha, 1 to 2 ha, 2 to 10 ha, 10 to 50 ha, 50 to 100 ha, and more than 100 ha. Finally, the occupation census in 1895 classifies farms in 7 groups: up to 0.5 ha, 0.5 to 2 ha, 2 to 5 ha, 5 to 20 ha, 20 to 100 ha, and more than 100 ha. Our measure for the concentration of large landownership is based on the share of farms larger than 300 PM or 100 ha, respectively.

Our rich data set allows us to account for several potential confounding factors. In particular, our analysis includes control variables for religious affiliation, urbanization, the share of people employed in industry, the share of people employed in agriculture, the child dependency ratio (defined as the ratio of people aged 0-14/18 over the working population between 15/19 and 65/70 years), population density, and school density. We also include a binary variable for the inheritance rule: the north-eastern parts of Prussia are dominated by non-partible inheritance (Anerbenrecht), while the south-western parts are

\footnotetext{
${ }^{13}$ In a few cases enrollment rates exceed 100 per cent. This could be due to children commuting from neighboring counties or because of children older than 14 years being enrolled in school.

${ }^{14}$ One PM is equal to circa 0.25 hectare.
} 
characterized by partible inheritance (Realteilung). These different rules likely affected the average size and the distribution of land holdings and might therefore influence our relationships of interest. We also include a control for the share of people whose first language is not German. In this way we can account for the ethnic-linguistic heterogeneity of the population. Finally, we include a measure for the sex-ratio, defined as the ratio of men over women, which is an important determinant of the female marriage rate.

Descriptive statistics of these variables for the five time-periods are presented in Table 3. The increasing number of observations at the bottom of the table reflects the formation and acquisition of new territories over the course of the nineteenth century. One can immediately observe a high initial level of enrollment of $60 \%$ in 1816 that increased to more than $90 \%$ at the end of the nineteenth century. On the contrary, we observe a decrease in the average female marriage rate from $54 \%$ to $50 \%$, a substantial drop given the slow moving character of adult marriage rates. The descriptive statistics further show that the share of large landholdings increased during the first half of the nineteenth century, reaching a share of 2.5 percent in 1858. Because of the change in the unit of measurement and in the definition of large landownership, we cannot directly compare the figures for the first three period with those of the last two periods. In the regression analysis we will use standardized values for landownership concentration (mean zero and unit standard deviation) as to eliminate biases due to the unit of measurement.

The descriptive statistics document trends in urbanization as well as in industrialization and population density over the course of the century. The apparent strong changes in the share of people employed in agriculture over time can be explained by inconsistencies in the definition of agricultural laborers. Religious affiliation, linguistic heterogeneity, inheritance rule, and the sex-ratio are rather time-invariant.

\section{Land Inequality and Education}

\subsection{Cross-sectional Evidence}

This section provides cross-sectional evidence for the relationship between landownership concentration and education. The relationship is estimated in five separate cross sections spanning the entire nineteenth century, for the years 1816, 1849, 1864, 1886, 1896. Cinnirella and Hornung (2016) find a significant negative relationship between landownership concentration and education in these five cross-sections. In their paper the administrative borders are held constant resembling the administrative structure in place around 1816 to allow for the highest possible comparability over time. However, throughout the century Prussia acquired vast new territories in central Germany. ${ }^{15}$ These territories, west of the

\footnotetext{
${ }^{15}$ Acquisitions include Hohenzollern (1850), Schleswig and Holstein (1865), the Kingdom of Hanover (1866), the Electorate of Hesse (1866), the Duchy of Nassau (1866), the free City of Frankfurt (1866), and Saxe-Lauenburg (1876).
} 
river Elbe, fill the gap between the eastern and the western part of Prussia, and might add significant variation to the data.

Table 4 shows cross-sectional results using the actual county structure in place at the time of each of the censuses, including the newly acquired territories. We also control for a range of demand and supply factors that might have an effect on enrollment rates. The estimates indicate a significant negative association of the share of large landownership with the enrollment rate for each time period. Since we standardize the share of large landownership with mean zero and unit standard deviation, we can directly compare the magnitude of the coefficients over time. The pattern of results suggests that the relationship decreases throughout the nineteenth century. A one standard deviation increase in landownership concentration (for example from the average value of $1.7 \%$ to $3.8 \%$ in 1816) translates into a 7 p.p. decrease in enrollment rates in 1816 but only to a 0.7 p.p. decrease in 1896. These findings are in line with the previous findings by Cinnirella and Hornung (2016) and confirm that the negative relationship between landownership concentration and education holds true when including the vast new territories in central Germany.

This chapter does not aim to establish causality in the relationship under analysis. By using contemporary census information on the geological composition of the soil, i.e. the amount of sand, clay and loam in the terrain (soil-texture), Cinnirella and Hornung (2016) identify exogenous variation in farm-size and therefore in the concentration of large landownership. The identification strategy is based on the notion that differences in soil-texture are related to differences in soil quality which historically generated a heterogeneous demand for land. In this way they provide two-stage least squares estimates of the relationship of interest and address the issue of causality. Instrumental variable estimates confirm a significant negative effect of large landownership for the years 1816 and 1849, whereas the coefficients for the other time periods are not statistically different from zero. Since the historical data on soil-texture are not available for the Prussian territories acquired in the second half of the century, we refrain from providing instrumental variable estimates here.

\subsection{Panel Analysis}

The cross-sectional results are likely to be afflicted by unobserved heterogeneity at the county level. We thus proceed to analyze the relationship of interest using the panel structure of the data. Since data for the newly acquired territories are not available for 
the early periods, we proceed to aggregate the data to the administrative structure in place at the beginning of the period, similar to Cinnirella and Hornung (2016). ${ }^{16}$

We start by showing bivariate estimates in the pooled sample in column 1 of Table 5 ; this shows the average relationship between landownership concentration and education throughout the nineteenth century. Column 2 excludes time-invariant unobserved heterogeneity by introducing a full set of county- and time-fixed effects. According to the results, a standard deviation increase in landownership concentration decreases enrollment rates by 2 percentage points. Controlling for various county characteristics in column 3 leaves the coefficient virtually unaffected. ${ }^{17}$

Although we account for time-invariant heterogeneity across counties, time-varying characteristics that affect both landownership and education might bias our fixed-effects estimates. In particular, if crops differ regarding their human capital intensity, time heterogeneity in the productivity of the soil could be an important omitted variable. In column 4 we address these concerns by including controls for land rent and crop yields. ${ }^{18}$ Since land rent is time-invariant and was only determined in 1865 , we interact the variable with the different time-periods. Similarly, information on yields per hectare are available for the years 1886 and 1896. For the earlier time-periods (1816, 1849, and 1864), we compute the average across the available year 1886 and 1896 and interact it with the time-period dummies. The results indicate that such controls do not affect the relationship between land concentration and education.

Finally, in columns 5 and 6 we estimate our model for the counties west and east of the river Elbe, respectively. As already mentioned, the two parts differ regarding the extent of serfdom and the level of development. Indeed, our panel estimates indicate that the relationship between landownership concentration and enrollment rates is negative and significant only for the eastern counties, where the authority of the landowners over the peasantry was more accentuated.

\section{Land Inequality, Education, and Marriage}

The previous section provided evidence for a negative relationship between landownership concentration and human capital formation. We have shown that the negative impact of large landownership on education can be detected when analyzing variation between counties as well as within counties.

\footnotetext{
${ }^{16}$ Changes in the administrative boundaries throughout the nineteenth century complicate the analysis of Prussian countylevel data. Becker et al. (2014) provide instructions on how to merge data sets from different sources and time-periods to obtain a panel structure.

${ }^{17}$ These results were first shown in Cinnirella and Hornung (2016).

${ }^{18}$ The variable for land rent is based on the Grundsteuerreinertrag defined as the income from agrarian use of land less the costs of farming (Kopsidis and Wolf, 2012). Crop yields refer to yields of wheat and rye.
} 


\subsection{Land Inequality and the Female Marriage Rate}

In section 4.3 we have discussed the potential role that large landowners might have played in peasants' marriage decisions. In this section we test whether landownership concentration is in fact associated with marriage patterns. We start by estimating crosssectional models for each time period:

$$
y_{i}^{t}=\beta \cdot \operatorname{Land}_{i}^{t}+X_{i}^{\prime} \gamma+\varepsilon
$$

where $y$ is the share of married women in county $i$, Land is the share of large landowners. ${ }^{19}$ The superscript $t$ refers to the time period. The vector of covariates $X$ includes urbanization, the share of Protestants, the sex ratio, employment in industry and agriculture, and the share of non-German speakers - variables that likely affect marriage rates independent of land concentration. The results are reported in Table 6. As one can see, with the exception of the year 1864, the cross-sectional estimates do not show any significant relationship between landownership concentration and the share of married women. We find that the share of Protestants is positively related to female marriage rates, whereas urbanization presents a systematic negative correlation. The share of people employed in industry seems to be positively related to female marriage rates, especially in the second half of the nineteenth century.

The cross-sectional estimates can be severely affected by unobserved heterogeneity. Therefore we proceed to present panel estimates that account for time-invariant countyspecific factors which can be related to marriage patterns. We estimate the following model:

$$
y_{i t}=\alpha_{i}+\tau_{t}+\beta \cdot \operatorname{Land}_{i t}+X_{i t}^{\prime} \gamma+\varepsilon
$$

where $\alpha_{i}$ and $\tau_{t}$ are county and time-fixed effects, respectively. The panel estimates are presented in Table 7.

In column 1, when estimating the relationship using the five cross-sections pooled, results show a positive coefficient. Column 2, introduces time- and county-fixed effects. When exploiting only the within-county variation in the data the relationship between land concentration and the female marriage rate is insignificant and close to zero. The same result holds when including the set of control variables (column 3). Contrary to the cross-sectional estimates, within-county variation indicates that the share of Protestants is negatively related to the share of married women. That suggests the existence of a county-specific factor which affected both the share of Protestants and marriage rates.

\footnotetext{
${ }^{19}$ The share of married women is defined as the number of married women over the total number of women older than 15 years.
} 
The coefficient for the sex ratio and employment in industry are positively related to female marriage rates. ${ }^{20}$

In column 4 we add controls for land rent and agricultural yields in wheat and rye. Similar to the previous panel analysis we interact land rent and agricultural yields with the five time periods. ${ }^{21}$ These control variables should account for changes in land productivity which might have affected female marriage decisions. Accounting for land rent and crop yields does not change our findings: there is no significant relationship between the concentration of large landownership and the share of married women. Estimating the fixed-effects model separately for the East and the West (columns 5 and 6) does not yield heterogeneity in the relationship either.

\subsection{Education and the Female Marriage Rate}

Thus far, we have presented evidence for the relationship between the institutions prevailing from the feudal system and marriage rates. However, as discussed above, relative changes in female incomes might be the reason for changes in marriage rates. Since data on relative changes in income are unavailable for the period under observation, we will proxy income by an important determinant of income - the investment in education.

In this section, we test whether investments in education - that are to a large extent determined by variations in landownership concentration - are associated with different marriage patterns. According to the theoretical model of Galor and Weil (1996), an increase in capital-labor ratio raises the relative wage of women as female labor has a higher complementarity with capital than male labor. An increase in the relative female wage increases the opportunity cost of children, potentially lowering fertility. In the context of nineteenth-century Prussia, we will test whether higher investments in education, a proxy for higher returns to human capital and thus, possibly, higher employment opportunities for women, affected the marriage pattern. In fact, Figure 2 indicates that there is a significant negative relationship between female labor force participation in industry and the share of married women.

Further descriptive evidence indicates that education and female marriage rates are negatively related. Figure 3 shows the evolution of enrollment rates in primary schools and marriage rates over time across Prussian districts. The overall picture reveals a strong divergence over the century. Higher enrollment rates, arguably proxying for higher returns to education which are beneficial to women (who have a comparative advantage in non-manual tasks), seem to be negatively correlated with marriage rates.

\footnotetext{
${ }^{20}$ In Figure 2 we show the relationship between female marriage rates and female labor force participation in the industrial sector in 1882. As information on labor force participation by gender is unavailable for earlier periods, such a variable cannot be included in the panel analysis.

${ }^{21}$ See the appendix in Cinnirella and Hornung (2016) for more details on data on land rent and crop yields
} 
We test this hypothesis by estimating the relationship of interest using our panel dataset in a model similar to equation 2, substituting enrollment rates for land concentration. The results are presented in Table 8. Column 1 presents results from a simple bivariate pooled OLS regression: the estimated coefficient for the enrollment rate is negative and significant. In column 2 we include county and time-fixed effects. We find a significant negative relationship between enrollment rates and the share of married women. The finding is confirmed in column 3 after including the set of control variables: the relationship of interest remains negative and highly significant. The coefficients for the control variables confirm the previous pattern: both urbanization and Protestantism are associated with lower marriage rates. As expected, a higher sex ratio is positively related to the female marriage ratio - more men lead to a higher share of married women. Higher employment in the secondary sector is positively associated with female marriage rates. We interpret this coefficient as capturing an income effect (Galor and Weil, 1996; Becker, Murphy, and Tamura, 1990).

Consistent with the estimates presented in Table 7, we include additional controls for land rent and agricultural yields in column 4. The coefficient for enrollment rate remains significant and of similar magnitude. In column 5 we test whether, accounting for enrollment rates, land concentration has a 'residual' impact on female marriage rates. Consistent with the previous results, we still find that landownership concentration has no direct impact on the share of married women.

So far we have interpreted enrollment rates as a proxy for higher returns to education, which would be comparatively more beneficial to women. However, it is also interesting to estimate the relationship between lagged investments in education and current marriage rates. In this way we can capture, at least to some extent, the marriage decision of those women who were in school in the previous time period. ${ }^{22}$ Thus, in column 6 , we include lagged values of the enrollment rate. Indeed, we find a significant negative coefficient of similar magnitude, which indicates a strong persistence in the relationship of interest. Such an estimate also rules out the issue of reverse causality.

Finally, in columns 7 and 8, we estimate separate fixed-effects models for the counties west and east of the river Elbe. In both cases, we find a significant negative relationship between investments in education and the share of married women. The point estimates suggest that the relationship is stronger in the more industrialized western counties, where enrollment rates likely capture better employment opportunities and higher wages for women.

\footnotetext{
${ }^{22}$ Becker, Cinnirella, and Woessmann (2013) adopt a similar approach to estimate the effect of mothers' education on their fertility.
} 
In brief, by exploiting within-county variation and controlling for a large set of confounding factors, we find that land concentration is not directly related to marriage rates. Yet, increasing levels of primary school enrollment rates are strongly negatively associated with changes in the female marriage rate. This result is consistent with the hypothesis that higher enrollment rates capture higher returns to skills which were comparatively more beneficial to women, and resulted in higher female employment opportunities and higher female wages (Galor and Weil, 1996). We argue that such higher employment opportunities and wages for women determine the observed higher celibacy rate. Clearly, these are reduced-form estimates which do not allow any claim of causality and force us to be speculative. Yet, these preliminary findings, if confirmed by more thorough analysis, would suggest that higher returns to education and the accumulation of human capital, by offering more female employment opportunities and higher wages, played a crucial role in limiting fertility not only through the quantity-quality tradeoff (Becker, Cinnirella, and Woessmann, 2010, 2012) but also by increasing the female celibacy rate.

\section{Conclusion}

This chapter integrates two distinct parts of the literature on long-run development. A part of this literature analyzes the effect of inequality on development by focussing on the detrimental effect of inequality on investment in human capital. Another part of the literature analyzes the role of human capital investment in changing the female fertility choices that triggered the demographic transition.

After discussing the main theoretical models on the long-run determinants of human capital and reviewing the main empirical studies on the topic, we present some evidence for the relationship between land inequality and primary schooling in nineteenth century Prussia. We show that landownership concentration is negatively associated with enrollment rates over the course of the nineteenth century and that the relationship is robust to the introduction of a large set of confounding factors.

We further aim at integrating the literature by investigating the relationship between land inequality and female marriage patterns, a major determinant of female fertility choices. In particular we investigate to what extent the authority of noble landowners that prevailed even after the abolition of feudal institutions influenced female marriage rates. On one hand, the landed elite might have favored the formation of families to increase the labor-force bounded to land. On the other hand, the landed elite might have been interested in preserving a sufficient number of domestic servants who were required to remain celibate. In fact, cross-sectional and panel estimates do not reveal any 
systematic relationship between landownership concentration and the share of married women.

Yet, as land inequality evidentially affected investments in human capital we proceed to analyze the relationship between enrollment rates and the female marriage rate to understand whether inequality had an indirect effect on female fertility choices. We find evidence for a robust negative relationship between primary-school enrollment rates and female marriage rates in fixed-effects panel analysis. We argue that this relationship can be explained by the fact that, during the Industrial Revolution, the capital-labor ratio changed and increased the relative wage of women. In our empirical model higher enrollment rates proxy for higher returns to skills and thus higher employment opportunities for women. This, in turn, increased the economic independence of women and resulted in an increase in the female celibacy rate. These preliminary results, if confirmed, could imply that higher returns to education and the accumulation of human capital played a crucial role in limiting fertility not only through the quantity-quality tradeoff but also by increasing the female celibacy rate. 


\section{References}

Acemoglu, Daron, Davide Cantoni, Simon Johnson, and James A. Robinson. 2011. "The Consequences of Radical Reform: The French Revolution." American Economic Review 101 (7):3286-3307.

Acemoglu, Daron, Francisco A. Gallego, and J. A. Robinson. 2014. "IInstitutions, Human Capital, and Development." Annual Review of Economics 6:875-912.

Acemoglu, Daron, Simon Johnson, and James Robinson. 2001. "The Colonial Origins of Comparative Development." American Economic Review 91 (5):1369-1401.

2002. "Reversal of Fortune: Geography and Institutions in the Making of the Modern World Income Distribution." Quarterly Journal of Economics 117:1231-1294.

Acemoglu, Daron and James Robinson. 2000. "Why Did the West Extend the Franchise? Democracy, Inequality and Growth in Historical Perspective." Quarterly Journal of Economics 115 (4):1167-1199.

Acemoglu, Daron and James A. Robinson. 2006. Economic Origins of Dictatorship and Democracy. Cambridge: Cambridge University Press.

Alesina, Alberto and Dani Rodrik. 1994. "Distributive Politics and Economic Growth." Quarterly Journal of Economics 108:465-490.

Banerjee, Abhijit and Lakshimi Iyer. 2005. "History, Institutions, and Economic Performance: The Legacy of Colonial Land Tenure Systems in India." American Economic Review 95 (4):1190 - 1213.

Becker, Gary S., Kevin M. Murphy, and Robert Tamura. 1990. "Human Capital, Fertility, and Economic Growth." Journal of Political Economy 98:S12-S37.

Becker, Sascha O., Francesco Cinnirella, Erik Hornung, and Ludger Woessmann. 2014. "iPEHD - The ifo Prussian Economic History Database." Historical Methods: A Journal of Quantitative and Interdisciplinary History 47 (2):57-66.

Becker, Sascha O., Francesco Cinnirella, and Ludger Woessmann. 2010. "Education versus Fertility: Evidence from before the Demographic Transition." Journal of Economic Growth 15 (3):177 - 204.

- 2012. "The effect of investment in children's education on fertility in 1816 Prussia." Cliometrica $6(1): 29-44$

2013. "Does Women's Education Affect Fertility? Evidence from Pre-Demographic Transition Prussia." European Review of Economic History 17 (1):24-44.

Becker, Sascha O. and Ludger Woessmann. 2009. "Was Weber Wrong? A Human Capital Theory of Protestant Economic History." Quarterly Journal of Economics 124 (2):531 - 596.

Berdahl, Robert M. 1988. The Politics of the Prussian Nobility. New Jersey: Princeton University Press.

Bowman, Shearer Davis. 1980. "Antebellum Planters and Vormärz Junkers in Comparative Perspective." American Historical Review 85 (4):779 - 808.

Cinnirella, Francesco and Erik Hornung. 2016. "Landownership concentration and the expansion of education." Journal of Development Economics 121:135-152.

Clark, Gregory and Rowena Gray. 2014. "Geography is not destiny: geography, institutions and literacy in England, 1837-63." Oxford Economic Papers 66 (4):1042-1069.

de la Croix, David and Marie Vander Donckt. 2010. "Would Empowering Women Initiate the Demographic Transition in Least Developed Countries?" Journal of Human Capital 4 (2):85-129.

De Moor, Tine and Jan Luiten Van Zanden. 2010. "Girlpower. The European Marriage Pattern and Labor Markets in the North Sea Region in the Late Medieval and Early Modern Period." Economic History Review 63:1-33. 
Dell, Melissa. 2010. "The Persistent Effects of Peru's Mining Mita." Econometrica 78 (6):1863 - 1903.

Dennison, Tracy and Sheilagh Ogilvie. 2014. "Does the European Marriage Pattern explain Economic Growth?" Journal of Economic History 74:651-693.

Diebolt, Claude and Faustine Perrin. 2013a. "From Stagnation to Sustained Growth: The Role of Female Empowerment." AFC Working Papers Nr. 4 .

- 2013b. "From Stagnation to Sutained Growth: The Role of Female Empowerment." American Economic Review 103:545-49.

Easterly, W. 2007. "Inequality does Cause Underdevelopment: Insights From a new Instrument." Journal of Development Economics 84:755 - 776 .

Eddie, Sean A. 2013. Freedom's Price: Seifdom, Subjection, and Reform in Prussia, 1648-1848. Oxford.

Engerman, Stanley L. and Kenneth L. Sokoloff. 1997. "Factor Endowments, Institutions, and Differential Paths of Growth among New World Economies: A View from Economic Historians of the United States." In How Latin America fell behind: Essays on the economic histories of Brazil and Mexico, 1800-1914, edited by Stephen H. Haber. Stanford University Press, 260 - 304.

Foreman-Peck, J. 2011. "The Western European Marriage Pattern and Economic Development." Explorations in Economic History 48:292-309.

Gallego, Francisco A. 2010. "Historical Origins of Schooling: The Role of Democracy and Political Decentralization." Review of Economics and Statistics 92 (2):228-243.

Galor, Oded. 2011. Unified Growth Theory. Princeton University Press.

Galor, Oded and Omer Moav. 2006. "Das Human-Kapital: A Theory of the Demise of the Class Structure." Review of Economic Studies 73 (1):85 - 117.

Galor, Oded, Omer Moav, and Dietrich Vollrath. 2009. "Inequality in Land Ownership, the Emergence of Human Capital Promoting Institutions and the Great Divergence." Review of Economic Studies $76(1): 143-179$.

Galor, Oded and David Weil. 1996. "The Gender Gap, Fertility, and Growth." American Economic Review 86:374-387.

Go, Sun and Peter Lindert. 2010. "The Uneven Rise of American Public Schools to 1850." Journal of Economic History 70 (1):1 - 26.

Hajnal, J. 1965. "European Marriage Pattern in Perspective." In Population in History. London: Arnold: D.V. Glass and D.E.C. Eversley.

Harnisch, Helmut. 1984. Kapitalistische Agrarreform und Industrielle Revolution. Weimar: Hermann Böhlaus Nachfolger.

Iyigun, Murat and Randall P. Walsh. 2007. "Endogenous gender power, household labor supply and the demographic transition." Journal of Development Economics 82:138-155.

Königliches Statistisches Bureau in Berlin. 1889. Preussische Statistik, vol. 101. Ernst Kuehn.

Kopsidis, Michael and Nikolaus Wolf. 2012. "Agricultural Productivity Across Prussia During the Industrial Revolution: A Thuenen Perspective." Journal of Economic History 72 (3):634-670.

Kourtellos, Andros, Ioanna Stylianou, and Chih Ming Tan. 2013. "Failure to Launch? The Role of Land Inequality in Transition Delays." European Economic Review 62.

Kuhlemann, Frank-Michael. 1991. "Schule, Hochschulen, Lehrer." In Handbuch der deutschen Bildungsgeschichte, vol. 4. 1870-1918: Von der Reichsgründung bis zum Ende des Ersten Weltkriegs, edited by Christa Berg. Verlag C.H. Beck, München, $170-370$. 
Lagerlöf, Nils-Petter. 2003. "Gender Equality and Long-Run Growth." Journal of Economic Growth 8:403-426.

Lindert, Peter H. 2003. "Voice and Growth: Was Churchill Right?" Journal of Economic History $63(2): 315-350$.

2004. Growing public: Social Spending and Economic Growth Since the Eighteenth Century. Cambridge: Cambridge University Press.

Mariscal, E. and Kenneth L. Sokoloff. 2000. "Schooling, Suffrage, and Inequality in the Americas, 18001945." In Political Institutions and Economic Growth in Latin America. Essay in Policy, History, and Political Economy, edited by Stephen H. Haber. Hoover Institution Press, Stanford, 159 - 218.

Naidu, Suresh. 2012. "Suffrage, Schooling, and Sorting in the Post-Bellum U.S. South." Working Paper 18129, National Bureau of Economic Research.

Neugebauer, Wolfgang. 1992. "Das Bildungswesen in Preußen seit der Mitte des 17. Jahrhunderts." In Handbuch der preussischen Geschichte, vol. 2, edited by Otto Büsch. Walter de Gruyter, Berlin, New York, $605-799$.

Nunn, Nathan. 2008. "Slavery, Inequality, and Economic Development in the Americas: An Examination of the Engerman-Sokoloff Hypothesis." In Institutions and Economic Performance, edited by E. Helpman. Cambridge: Harvard University Press.

Ogilvie, Sheilagh. 2005. "Communities and the 'Second Serfdom' in Early Modern Bohemia." Past \& Present 187:69-119.

Persson, Torsten and Guido Tabellini. 1994. "Is Inequality Harmful for Growth? Theory and Evidence." American Economic Review 84 (3):600 - 621.

Pierenkemper, Toni and Richard Tilly. 2004. The German Economy during the Nineteenth Century. New York and Oxford: Berghahn Books.

Ramcharan, Rodney. 2010. "Inequality and Redistribution: Evidence from U.S. Counties and States, 1890-1930." Review of Economics and Statistics 92 (4):729-744.

Rosenberg, Hans. 1944. "The Rise of the Junkers in Brandenburg-Prussia, 1410-1653: Part 2." American Historical Review 49 (2):228 - 242.

Schleunes, Karl A. 1979. "Enlightenment, Reform, Reaction: The Schooling Revolution in Prussia." Central European History 12:315 - 342.

Sokoloff, K. L. and S. Engerman. 2000. "Institutions, Factor Endowments, and Paths of Development in the New World." Journal of Economic Perspectives 14:217-232.

Voigtländer, Nico and Hans-Joachim Voth. 2013. "How the West 'Invented' Fertility Restriction." American Economic Review 103:2227-64.

Vollrath, Dietrich. 2013. "School Funding and Inequality in the United States, 1890." Explorations in Economic History 50 (2):267-284.

Wrigley, Edward Anthony. 2006. Industrial Growth and Population Change. Cambridge University Press. 
Figure 1: Development of the primary school enrollment rate in Prussia, 1816-1900

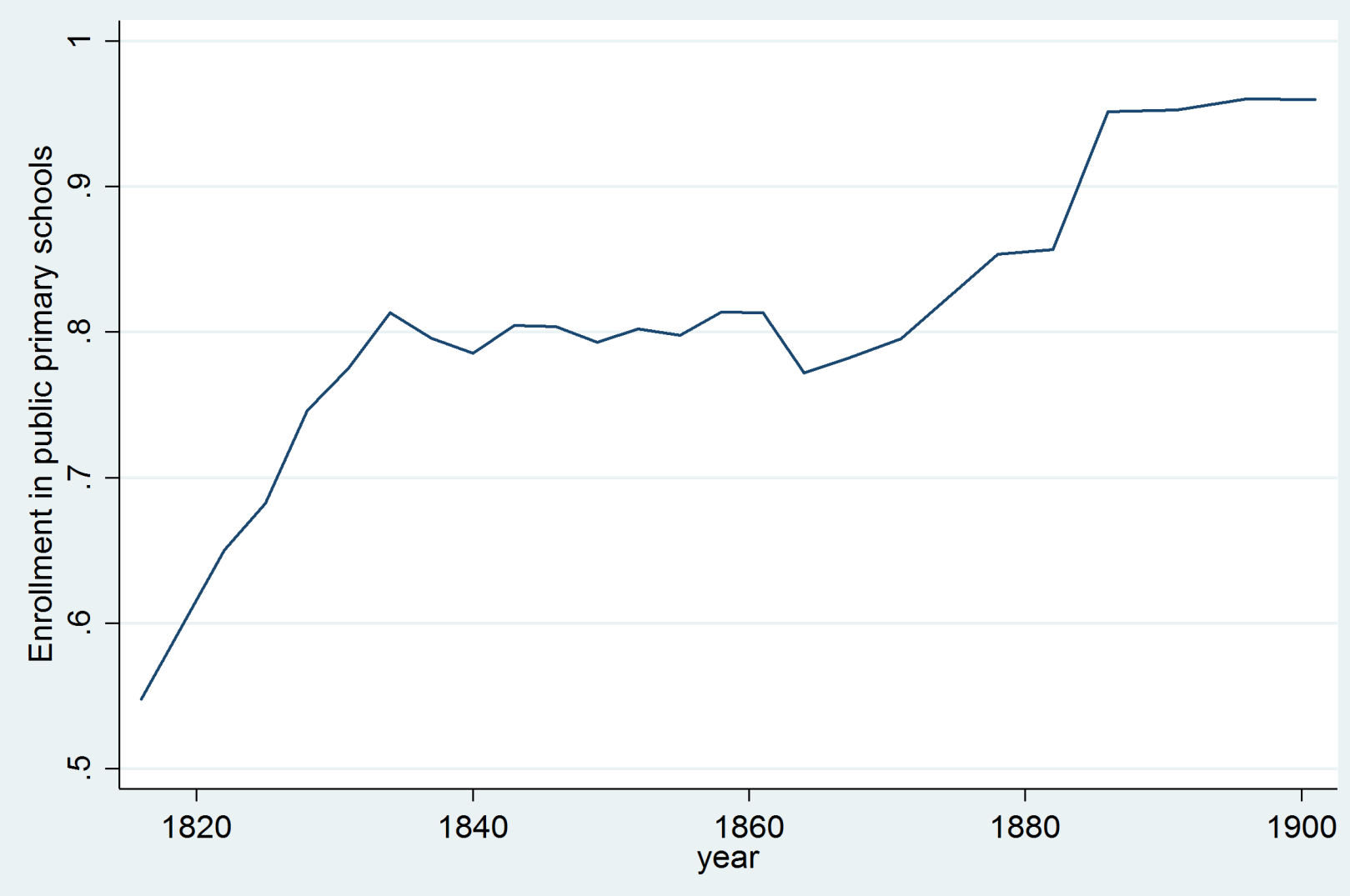

Source: Prussian census data 
Figure 2: Female marriage and female labor force participation rate

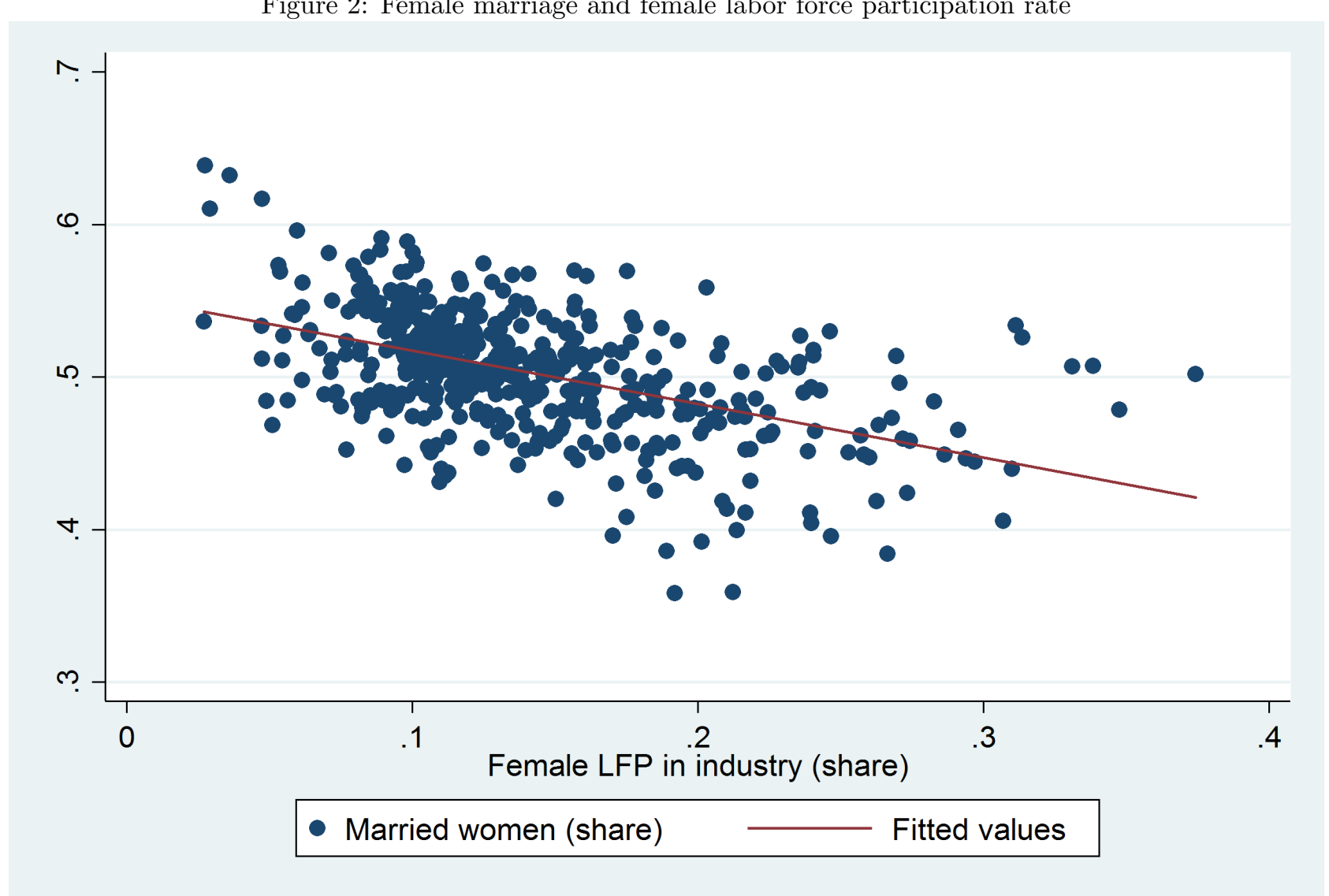

Source: Prussian census data 
Figure 3: Female marriage and enrollment rates

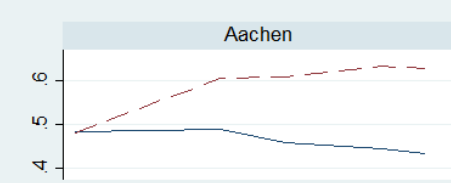

Düsseldorf
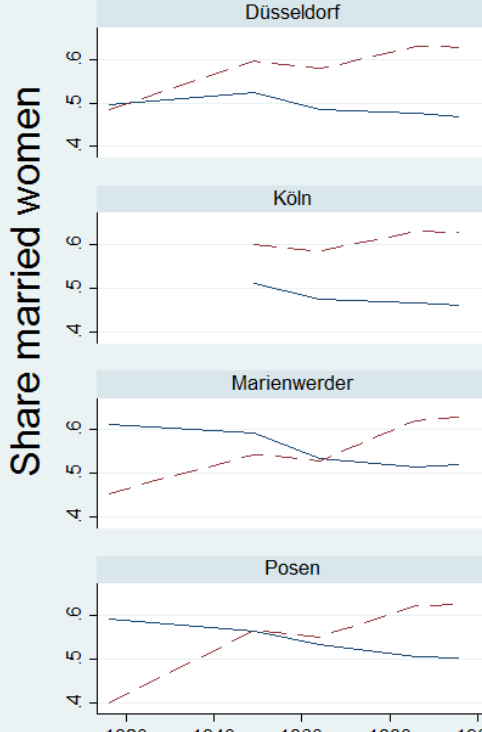

$\begin{array}{lllll}1820 & 1840 & 1860 & 1880 & 1900\end{array}$

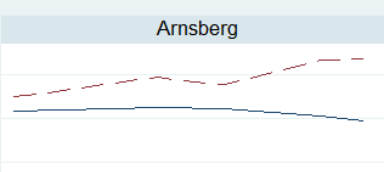

Erfurt

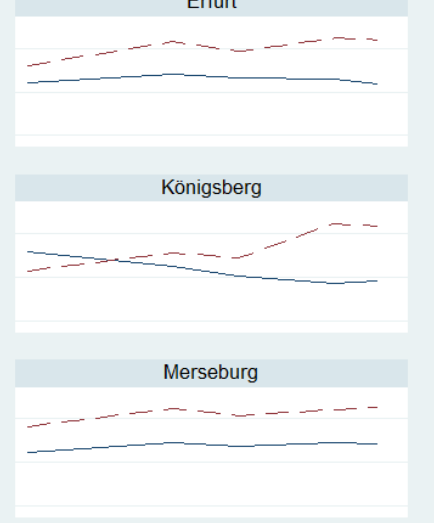

Potsdam

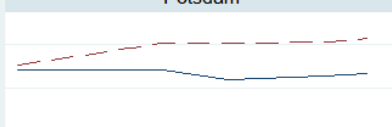

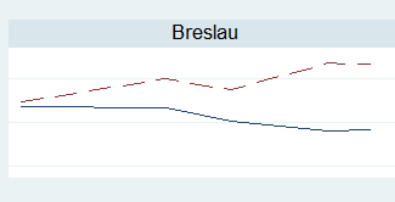

Frankfurt
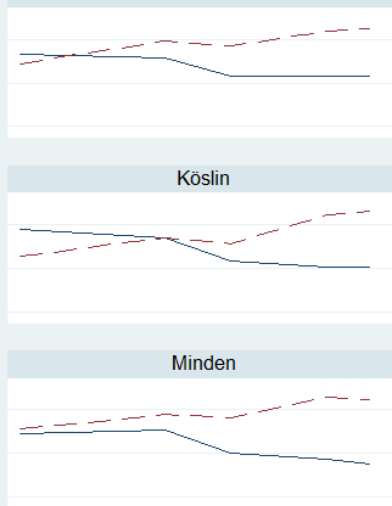

Stettin

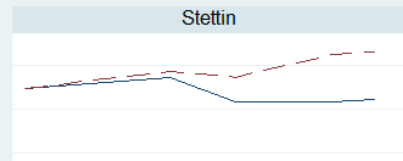

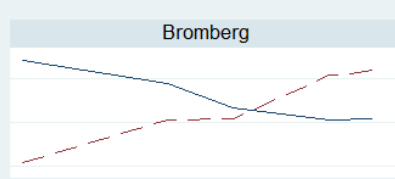

Gumbinnen
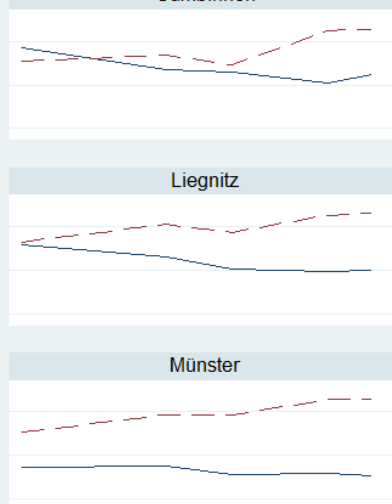

Stralsund

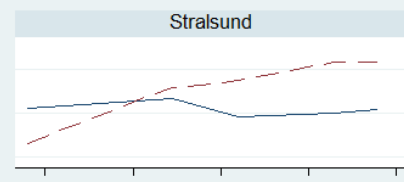

- - - - Enrollment rate (6-14)

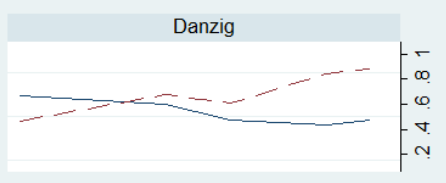

Koblenz
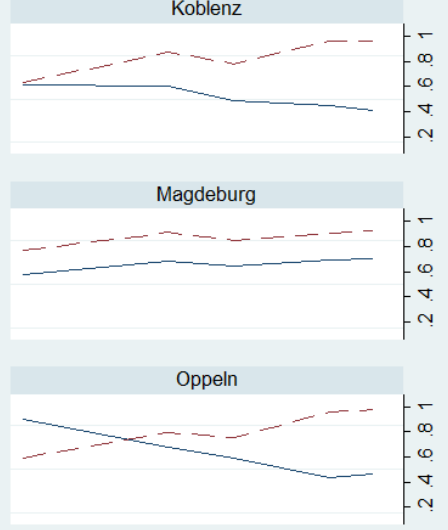

Trier

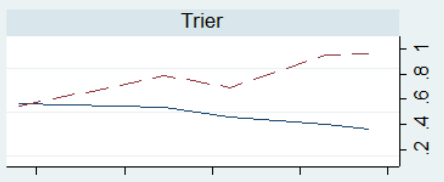

\begin{tabular}{lllll}
\hline 1820 & 1840 & 1860 & 1880 & 1900
\end{tabular}

Share married women

Source: Prussian census data 
Table 1: Total expenditure for public primary schools, 1861-86

\begin{tabular}{|c|c|c|c|c|c|c|}
\hline & 1861 & 1864 & 1867 & 1871 & 1878 & 1886 \\
\hline Eastprussia & 1.414 & 1.469 & 1.723 & 1.781 & 3.053 & 3.637 \\
\hline Westprussia & 1.458 & 1.603 & 1.798 & 1.915 & 3.124 & 3.673 \\
\hline Poznan & 1.190 & 1.253 & 1.399 & 1.695 & 2.687 & 3.508 \\
\hline Silesia & 1.276 & 1.337 & 1.517 & 1.716 & 2.792 & 3.488 \\
\hline Pomerania & 1.670 & 1.727 & 1.945 & 2.305 & 3.668 & 4.533 \\
\hline Brandenburg & 1.963 & 1.953 & 2.109 & 2.468 & 3.515 & 4.220 \\
\hline Saxony & 2.079 & 2.124 & 2.233 & 2.536 & 3.727 & 4.678 \\
\hline Westphalia & 1.559 & 1.597 & 1.812 & 2.110 & 3.840 & 4.742 \\
\hline
\end{tabular}

Note: Total expenditure for public primary schools in German Marks per capita at the province level.

Source: Own calculations according to Königliches Statistisches Bureau in Berlin (1889).

Table 2: State expenditures for public primary schools, 1861-86

\begin{tabular}{|c|c|c|c|c|c|c|}
\hline & 1861 & 1864 & 1867 & 1871 & 1878 & 1886 \\
\hline Eastprussia & 0.079 & 0.077 & 0.095 & 0.142 & 0.636 & 0.742 \\
\hline Westprussia & 0.103 & 0.096 & 0.111 & 0.169 & 0.499 & 0.667 \\
\hline Poznan & 0.085 & 0.080 & 0.103 & 0.141 & 0.638 & 0.798 \\
\hline Silesia & 0.035 & 0.038 & 0.050 & 0.074 & 0.325 & 0.424 \\
\hline Pomerania & 0.063 & 0.052 & 0.060 & 0.119 & 0.807 & 0.908 \\
\hline Brandenburg & 0.111 & 0.083 & 0.106 & 0.129 & 0.461 & 0.501 \\
\hline Saxony & 0.090 & 0.068 & 0.079 & 0.109 & 0.356 & 0.378 \\
\hline Westphalia & 0.058 & 0.044 & 0.069 & 0.096 & 0.392 & 0.376 \\
\hline
\end{tabular}

Note: State expenditures for public primary schools in German Marks per capita at the province level.

Source: Own calculations according to Königliches Statistisches Bureau in Berlin (1889). 
Table 3: Descriptive statistics

\begin{tabular}{|c|c|c|c|c|c|}
\hline VARIABLES & $\begin{array}{c}(1) \\
1816\end{array}$ & $\begin{array}{c}(2) \\
1849 \\
\end{array}$ & $\begin{array}{c}(3) \\
1864 \\
\end{array}$ & $\begin{array}{c}(4) \\
1886 \\
\end{array}$ & $\begin{array}{c}(5) \\
1896 \\
\end{array}$ \\
\hline Enrollment rate (6-14) & $\begin{array}{c}0.603 \\
(0.195)\end{array}$ & $\begin{array}{c}0.802 \\
(0.117)\end{array}$ & $\begin{array}{c}0.753 \\
(0.104)\end{array}$ & $\begin{array}{c}0.936 \\
(0.077)\end{array}$ & $\begin{array}{c}0.943 \\
(0.076)\end{array}$ \\
\hline Large landholdings (share) & $\begin{array}{c}0.017 \\
(0.021)\end{array}$ & $\begin{array}{c}0.024 \\
(0.027)\end{array}$ & $\begin{array}{c}0.025 \\
(0.026)\end{array}$ & $\begin{array}{c}0.008 \\
(0.008)\end{array}$ & $\begin{array}{c}0.006 \\
(0.007)\end{array}$ \\
\hline Married women (share) & $\begin{array}{c}0.544 \\
(0.054)\end{array}$ & $\begin{array}{c}0.541 \\
(0.046)\end{array}$ & $\begin{array}{c}0.511 \\
(0.039)\end{array}$ & $\begin{array}{c}0.502 \\
(0.041)\end{array}$ & $\begin{array}{c}0.504 \\
(0.045)\end{array}$ \\
\hline Protestant (share) & $\begin{array}{c}0.616 \\
(0.402)\end{array}$ & $\begin{array}{c}0.605 \\
(0.394)\end{array}$ & $\begin{array}{c}0.600 \\
(0.391)\end{array}$ & $\begin{array}{c}0.642 \\
(0.374)\end{array}$ & $\begin{array}{c}0.645 \\
(0.367)\end{array}$ \\
\hline Urban (share) & $\begin{array}{c}0.244 \\
(0.182)\end{array}$ & $\begin{array}{c}0.246 \\
(0.186)\end{array}$ & $\begin{array}{c}0.260 \\
(0.194)\end{array}$ & $\begin{array}{c}0.295 \\
(0.242)\end{array}$ & $\begin{array}{c}0.317 \\
(0.275)\end{array}$ \\
\hline Industrial (share) & $\begin{array}{c}0.009 \\
(0.023)\end{array}$ & $\begin{array}{c}0.072 \\
(0.039)\end{array}$ & $\begin{array}{c}0.080 \\
(0.048)\end{array}$ & $\begin{array}{c}0.119 \\
(0.058)\end{array}$ & $\begin{array}{c}0.127 \\
(0.062)\end{array}$ \\
\hline Agricultural (share) & $\begin{array}{c}0.088 \\
(0.038)\end{array}$ & $\begin{array}{c}0.550 \\
(0.187)\end{array}$ & $\begin{array}{c}0.186 \\
(0.066)\end{array}$ & $\begin{array}{c}0.196 \\
(0.079)\end{array}$ & $\begin{array}{c}0.188 \\
(0.090)\end{array}$ \\
\hline Child dependency ratio & $\begin{array}{c}0.631 \\
(0.074)\end{array}$ & $\begin{array}{c}0.646 \\
(0.077)\end{array}$ & $\begin{array}{c}0.602 \\
(0.067)\end{array}$ & $\begin{array}{c}0.894 \\
(0.111)\end{array}$ & $\begin{array}{c}0.773 \\
(0.105)\end{array}$ \\
\hline Population density & $\begin{array}{c}0.760 \\
(1.855)\end{array}$ & $\begin{array}{c}1.774 \\
(8.430)\end{array}$ & $\begin{array}{c}2.236 \\
(11.238)\end{array}$ & $\begin{array}{c}4.135 \\
(16.231)\end{array}$ & $\begin{array}{c}5.237 \\
(17.597)\end{array}$ \\
\hline School density & $\begin{array}{c}0.131 \\
(0.263)\end{array}$ & $\begin{array}{c}0.177 \\
(0.730)\end{array}$ & $\begin{array}{c}0.195 \\
(0.756)\end{array}$ & $\begin{array}{c}0.178 \\
(0.336)\end{array}$ & $\begin{array}{c}0.201 \\
(0.360)\end{array}$ \\
\hline Inheritance (dummy) & $\begin{array}{c}0.246 \\
(0.432)\end{array}$ & $\begin{array}{c}0.245 \\
(0.431)\end{array}$ & $\begin{array}{c}0.245 \\
(0.431)\end{array}$ & $\begin{array}{c}0.253 \\
(0.435)\end{array}$ & $\begin{array}{c}0.255 \\
(0.436)\end{array}$ \\
\hline Non-German speakers (share) & $\begin{array}{c}0.107 \\
(0.237)\end{array}$ & $\begin{array}{c}0.134 \\
(0.259)\end{array}$ & $\begin{array}{c}0.134 \\
(0.259)\end{array}$ & $\begin{array}{c}0.106 \\
(0.242)\end{array}$ & $\begin{array}{c}0.119 \\
(0.245)\end{array}$ \\
\hline Sex ratio & $\begin{array}{c}0.962 \\
(0.057)\end{array}$ & $\begin{array}{c}0.992 \\
(0.046)\end{array}$ & $\begin{array}{c}0.966 \\
(0.048)\end{array}$ & $\begin{array}{c}0.962 \\
(0.055)\end{array}$ & $\begin{array}{c}0.968 \\
(0.063)\end{array}$ \\
\hline Observations & 272 & 335 & 335 & 463 & 549 \\
\hline
\end{tabular}

Note: Standard deviation in parenthesis.

Source: See Cinnirella and Hornung (2016) for data sources and details. 
Table 4: Land concentration and enrollment rates - OLS estimates

\begin{tabular}{lccccc}
\hline & $(1)$ & $(2)$ & $(3)$ & $(4)$ & $(5)$ \\
VARIABLES & 1816 & 1849 & 1864 & 1886 & 1896 \\
\hline \multirow{2}{*}{ Share of large landholdings (std) } & $-0.070^{* * *}$ & $-0.038^{* * *}$ & $-0.032^{* * *}$ & $-0.009^{* * *}$ & $-0.007^{* * *}$ \\
& $(0.010)$ & $(0.007)$ & $(0.005)$ & $(0.002)$ & $(0.002)$ \\
Protestant (share) & $0.189^{* * *}$ & $0.055^{* * *}$ & $0.045^{* * *}$ & $0.016^{* *}$ & $0.015^{* *}$ \\
& $(0.031)$ & $(0.016)$ & $(0.013)$ & $(0.008)$ & $(0.006)$ \\
Urban (share) & -0.078 & $-0.086^{* *}$ & 0.043 & $-0.133^{* * *}$ & $-0.101^{* * *}$ \\
& $(0.064)$ & $(0.041)$ & $(0.056)$ & $(0.022)$ & $(0.019)$ \\
Industrial (share) & $-0.440^{*}$ & 0.117 & 0.312 & $0.615^{* * *}$ & $0.497^{* * *}$ \\
& $(0.232)$ & $(0.142)$ & $(0.201)$ & $(0.120)$ & $(0.078)$ \\
Agricultural (share) & 0.232 & -0.022 & $0.320^{*}$ & $0.629^{* * *}$ & $0.489^{* * *}$ \\
& $(0.274)$ & $(0.036)$ & $(0.167)$ & $(0.107)$ & $(0.060)$ \\
Child dependency ratio & $-0.347^{* *}$ & -0.057 & $-0.186^{* *}$ & $0.182^{* * *}$ & $0.251^{* * *}$ \\
Population density & $(0.137)$ & $(0.083)$ & $(0.089)$ & $(0.035)$ & $(0.031)$ \\
& $-0.065^{* * *}$ & $-0.008^{* * *}$ & $-0.004^{* * *}$ & $-0.002^{* * *}$ & $-0.001^{*}$ \\
School density & $(0.014)$ & $(0.002)$ & $(0.001)$ & $(0.001)$ & $(0.001)$ \\
& $0.422^{* * *}$ & $0.087^{* * *}$ & $0.046^{* * *}$ & $0.114^{* * *}$ & $0.081^{* * *}$ \\
Inheritance (dummy) & $(0.090)$ & $(0.014)$ & $(0.010)$ & $(0.032)$ & $(0.027)$ \\
Non-German speakers (share) & -0.003 & $0.021^{*}$ & $0.029^{* *}$ & -0.000 & 0.002 \\
& $(0.026)$ & $(0.012)$ & $(0.012)$ & $(0.007)$ & $(0.006)$ \\
Observations & $-0.205^{* * *}$ & $-0.158^{* * *}$ & $-0.135^{* * *}$ & $-0.038^{* * *}$ & -0.015 \\
R-squared & $(0.059)$ & $(0.028)$ & $(0.024)$ & $(0.012)$ & $(0.010)$ \\
\hline & & & & & \\
Note: The table & 272 & 335 & 335 & 463 & 549 \\
& 0.46 & 0.38 & 0.40 & 0.59 & 0.61 \\
\hline
\end{tabular}

Note: The table shows county-level OLS estimates for five separate cross-sections. Land concentration is standardized with mean zero and unit standard deviation. Robust standard errors in parentheses. Significance: ${ }^{* * *} \mathrm{p}<0.01,{ }^{* *} \mathrm{p}<0.05,{ }^{*} \mathrm{p}<0.1$.

Source: See Cinnirella and Hornung (2016) for data sources and details. 
Table 5: Land concentration and enrollment rates - Panel estimates

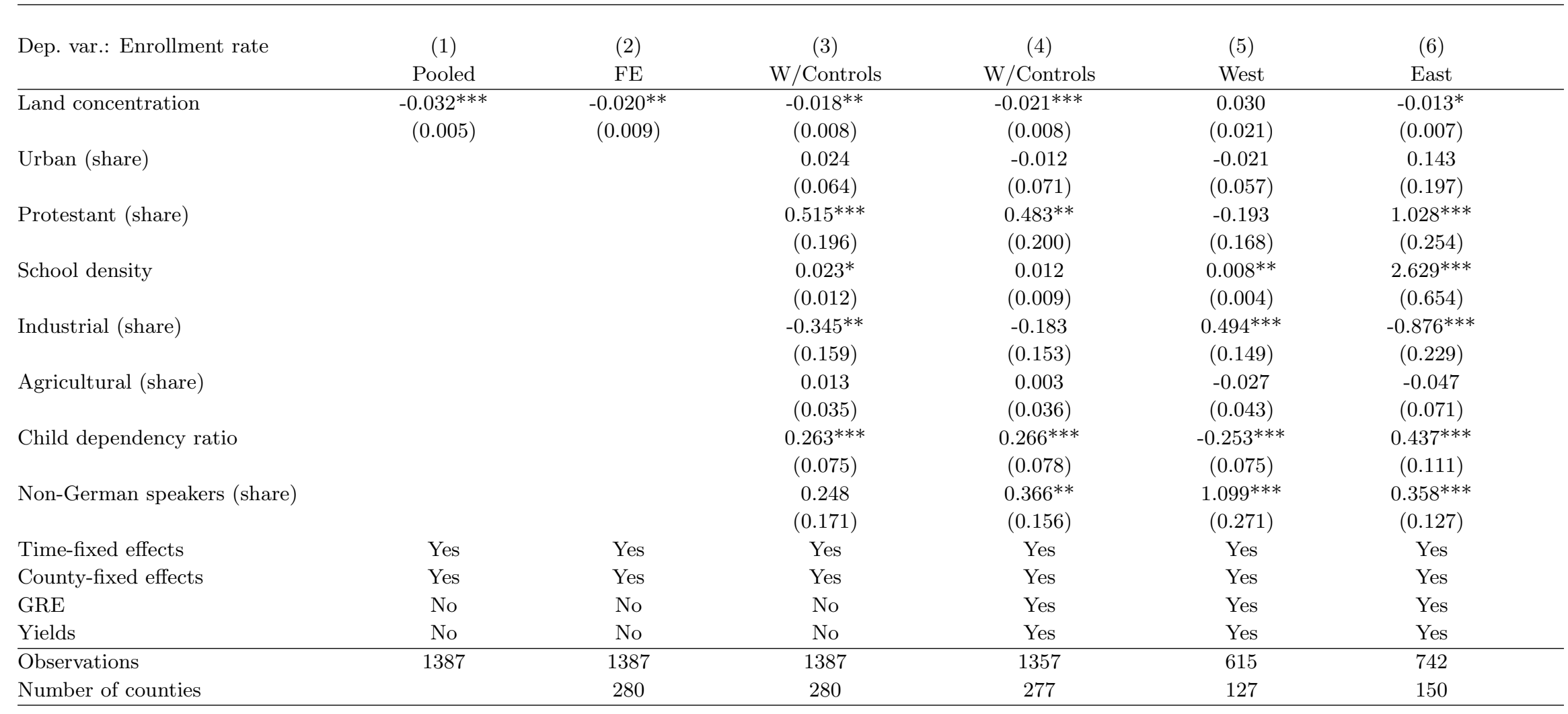

Note: The table shows county-level panel estimates. Measures of land concentration are standardized with mean zero and unit standard deviation. Standard errors in parentheses are clustered at the county level. 13 observations drop out from the analysis because of missing information for the district of Cologne in the 1816 data. Significance: ${ }^{* * *} \mathrm{p}<0.01,{ }^{* *} \mathrm{p}<0.05,{ }^{*} \mathrm{p}<0.1$.

Source: See Cinnirella and Hornung (2016) for data sources and details. 
Table 6: Female marriage and land concentration - OLS estimates

\begin{tabular}{lccccc}
\hline & $(1)$ & $(2)$ & $(3)$ & $(4)$ & $(5)$ \\
VARIABLES & 1816 & 1849 & 1864 & 1886 & 1896 \\
\hline \multirow{2}{*}{ Share of large landholdings (std) } & 0.004 & $0.006^{* *}$ & -0.001 & 0.000 & 0.002 \\
& $(0.003)$ & $(0.002)$ & $(0.002)$ & $(0.001)$ & $(0.002)$ \\
Protestant (share) & $0.042^{* * *}$ & $0.040^{* * *}$ & $0.058^{* * *}$ & $0.065^{* * *}$ & $0.074^{* * *}$ \\
& $(0.008)$ & $(0.006)$ & $(0.005)$ & $(0.005)$ & $(0.005)$ \\
Urban (share) & $-0.085^{* * *}$ & $-0.097^{* * *}$ & $-0.069^{* * *}$ & $-0.072^{* * *}$ & $-0.073^{* * *}$ \\
& $(0.016)$ & $(0.019)$ & $(0.012)$ & $(0.013)$ & $(0.009)$ \\
Industrial (share) & $0.121^{*}$ & 0.036 & $0.147^{* * *}$ & $0.220^{* * *}$ & $0.257^{* * *}$ \\
& $(0.069)$ & $(0.050)$ & $(0.052)$ & $(0.059)$ & $(0.049)$ \\
Agricultural (share) & $-0.120^{*}$ & -0.022 & -0.018 & 0.027 & 0.028 \\
Population density & $(0.066)$ & $(0.016)$ & $(0.040)$ & $(0.056)$ & $(0.039)$ \\
Sex ratio & $-0.004^{* * *}$ & -0.001 & $-0.001^{* *}$ & -0.000 & -0.000 \\
& $(0.001)$ & $(0.001)$ & $(0.000)$ & $(0.000)$ & $(0.000)$ \\
Inheritance (dummy) & 0.161 & $0.167^{* * *}$ & $0.235^{* * *}$ & $0.259^{* * *}$ & $0.228^{* * *}$ \\
Non-German speakers (share) & $(0.101)$ & $(0.051)$ & $(0.038)$ & $(0.030)$ & $(0.026)$ \\
& -0.004 & -0.001 & 0.001 & -0.002 & -0.001 \\
& $(0.007)$ & $(0.005)$ & $(0.004)$ & $(0.004)$ & $(0.004)$ \\
Observations & $0.123^{* * *}$ & $0.056^{* * *}$ & $0.081^{* * *}$ & $0.053^{* * *}$ & $0.077^{* * *}$ \\
R-squared & $(0.013)$ & $(0.008)$ & $(0.006)$ & $(0.008)$ & $(0.009)$ \\
\hline
\end{tabular}

Note: The table shows county-level OLS estimates for five separate cross-sections. Robust standard errors in parentheses. Significance: ${ }^{* * *} \mathrm{p}<0.01,{ }^{* *} \mathrm{p}<0.05,{ }^{*} \mathrm{p}<0.1$.

Source: See Cinnirella and Hornung (2016) for data sources and details. 
Table 7: Female marriage and land concentration — Panel estimates

\begin{tabular}{|c|c|c|c|c|c|c|}
\hline Dep. var.: Share married women & $\begin{array}{c}(1) \\
\text { Pooled }\end{array}$ & $\begin{array}{l}(2) \\
\mathrm{FE}\end{array}$ & $\begin{array}{c}(3) \\
\mathrm{W} / \text { Controls }\end{array}$ & $\begin{array}{c}(4) \\
\mathrm{W} / \text { Controls }\end{array}$ & $\begin{array}{c}(5) \\
\text { West }\end{array}$ & $\begin{array}{c}(6) \\
\text { East }\end{array}$ \\
\hline Land concentration & $\begin{array}{c}0.012^{* * *} \\
(0.003)\end{array}$ & $\begin{array}{l}-0.001 \\
(0.002)\end{array}$ & $\begin{array}{l}-0.001 \\
(0.001)\end{array}$ & $\begin{array}{c}0.001 \\
(0.001)\end{array}$ & $\begin{array}{l}-0.003 \\
(0.004)\end{array}$ & $\begin{array}{l}-0.001 \\
(0.001)\end{array}$ \\
\hline Urban (share) & & & $\begin{array}{c}-0.066^{* * *} \\
(0.015)\end{array}$ & $\begin{array}{c}-0.057^{* * *} \\
(0.016)\end{array}$ & $\begin{array}{c}-0.074^{* * *} \\
(0.018)\end{array}$ & $\begin{array}{l}-0.046 \\
(0.029)\end{array}$ \\
\hline Protestant (share) & & & $\begin{array}{c}-0.158^{* * *} \\
(0.048)\end{array}$ & $\begin{array}{c}-0.122^{* * *} \\
(0.045)\end{array}$ & $\begin{array}{c}-0.122^{* *} \\
(0.057)\end{array}$ & $\begin{array}{c}-0.163^{* * *} \\
(0.052)\end{array}$ \\
\hline Sex ratio & & & $\begin{array}{c}0.245^{* * *} \\
(0.067)\end{array}$ & $\begin{array}{c}0.213^{* * *} \\
(0.069)\end{array}$ & $\begin{array}{c}0.058 \\
(0.042)\end{array}$ & $\begin{array}{c}0.452^{* * *} \\
(0.047)\end{array}$ \\
\hline Industrial (share) & & & $\begin{array}{c}0.278^{* * *} \\
(0.049)\end{array}$ & $\begin{array}{c}0.203^{* * *} \\
(0.044)\end{array}$ & $\begin{array}{c}0.226^{* * *} \\
(0.054)\end{array}$ & $\begin{array}{c}0.109 * * * \\
(0.034)\end{array}$ \\
\hline Agricultural (share) & & & $\begin{array}{c}0.018 \\
(0.015)\end{array}$ & $\begin{array}{c}0.003 \\
(0.015)\end{array}$ & $\begin{array}{l}-0.028 \\
(0.021)\end{array}$ & $\begin{array}{l}0.026^{*} \\
(0.015)\end{array}$ \\
\hline Non-German speakers (share) & & & $\begin{array}{l}0.034 \\
(0.030)\end{array}$ & $\begin{array}{l}-0.006 \\
(0.031)\end{array}$ & $\begin{array}{c}0.369 \\
(0.233)\end{array}$ & $\begin{array}{l}-0.035 \\
(0.026)\end{array}$ \\
\hline Time-fixed effects & No & Yes & Yes & Yes & Yes & Yes \\
\hline County-fixed effects & No & Yes & Yes & Yes & Yes & Yes \\
\hline GRE & No & No & No & Yes & Yes & Yes \\
\hline Yields & No & No & No & Yes & Yes & Yes \\
\hline Observations & 1387 & 1387 & 1387 & 1357 & 615 & 742 \\
\hline Number of counties & & 280 & 280 & 277 & 127 & 150 \\
\hline
\end{tabular}

Note: The table shows county-level panel estimates. Standard errors in parentheses are clustered at the county level. 13 observations drop out from the analysis because of missing information for the district of Cologne in the 1816 data. Significance: ${ }^{* * *} \mathrm{p}<0.01,{ }^{* *} \mathrm{p}<0.05,{ }^{*} \mathrm{p}<0.1$.

Source: See Cinnirella and Hornung (2016) for data sources and details. 
Table 8: Female marriage and enrollment rates — Panel estimates

\begin{tabular}{|c|c|c|c|c|c|c|c|c|}
\hline Dep. var.: Share married women & $\begin{array}{c}(1) \\
\text { Pooled }\end{array}$ & $\begin{array}{l}(2) \\
\text { FE }\end{array}$ & $(3)$ & $(4)$ & $(5)$ & $(6)$ & $\begin{array}{c}(7) \\
\text { West }\end{array}$ & $\begin{array}{c}(8) \\
\text { East }\end{array}$ \\
\hline$\overline{\text { Enrollment rate }(6-14)}$ & $\begin{array}{c}-0.080^{* * *} \\
(0.011)\end{array}$ & $\begin{array}{c}-0.085^{* * *} \\
(0.011)\end{array}$ & $\begin{array}{c}-0.056^{* * *} \\
(0.011)\end{array}$ & $\begin{array}{c}-0.049^{* * *} \\
(0.010)\end{array}$ & $\begin{array}{c}-0.048^{* * *} \\
(0.010)\end{array}$ & & $\begin{array}{c}-0.065^{* * *} \\
(0.015)\end{array}$ & $\begin{array}{c}-0.021^{*} \\
(0.011)\end{array}$ \\
\hline Lagged enrollment rate (6-14) & & & & & & $\begin{array}{c}-0.040^{* * *} \\
(0.008)\end{array}$ & & \\
\hline Land concentration & & & & & $\begin{array}{l}-0.000 \\
(0.001)\end{array}$ & & $\begin{array}{l}-0.001 \\
(0.004)\end{array}$ & $\begin{array}{l}-0.002 \\
(0.001)\end{array}$ \\
\hline Urban (share) & & & $\begin{array}{c}-0.062^{* * *} \\
(0.015)\end{array}$ & $\begin{array}{c}-0.057^{* * *} \\
(0.017)\end{array}$ & $\begin{array}{c}-0.058^{* * *} \\
(0.017)\end{array}$ & $\begin{array}{c}-0.063^{* * *} \\
(0.015)\end{array}$ & $\begin{array}{c}-0.074^{* * *} \\
(0.019)\end{array}$ & $\begin{array}{l}-0.045 \\
(0.030)\end{array}$ \\
\hline Protestant (share) & & & $\begin{array}{c}-0.143^{* * *} \\
(0.047)\end{array}$ & $\begin{array}{c}-0.103^{* *} \\
(0.046)\end{array}$ & $\begin{array}{c}-0.102^{* *} \\
(0.046)\end{array}$ & $\begin{array}{l}-0.051 \\
(0.053)\end{array}$ & $\begin{array}{c}-0.131^{* *} \\
(0.056)\end{array}$ & $\begin{array}{c}-0.140^{* *} \\
(0.054)\end{array}$ \\
\hline Sex ratio & & & $\begin{array}{c}0.217^{* * *} \\
(0.062)\end{array}$ & $\begin{array}{c}0.195^{* * *} \\
(0.065)\end{array}$ & $\begin{array}{c}0.195^{* * *} \\
(0.065)\end{array}$ & $\begin{array}{c}0.173^{* * *} \\
(0.029)\end{array}$ & $\begin{array}{c}0.057 \\
(0.039)\end{array}$ & $\begin{array}{c}0.431^{* * *} \\
(0.045)\end{array}$ \\
\hline Industrial (share) & & & $\begin{array}{c}0.256^{* * *} \\
(0.045)\end{array}$ & $\begin{array}{c}0.196^{* * *} \\
(0.041)\end{array}$ & $\begin{array}{c}0.198^{* * *} \\
(0.042)\end{array}$ & $\begin{array}{c}0.118^{* * *} \\
(0.043)\end{array}$ & $\begin{array}{c}0.253^{* * *} \\
(0.051)\end{array}$ & $\begin{array}{c}0.093^{* * *} \\
(0.034)\end{array}$ \\
\hline Agricultural (share) & & & $\begin{array}{c}0.014 \\
(0.015)\end{array}$ & $\begin{array}{c}0.002 \\
(0.015)\end{array}$ & $\begin{array}{c}0.002 \\
(0.015)\end{array}$ & $\begin{array}{c}0.006 \\
(0.019)\end{array}$ & $\begin{array}{l}-0.028 \\
(0.021)\end{array}$ & $\begin{array}{c}0.024 \\
(0.015)\end{array}$ \\
\hline Non-German speakers (share) & & & $\begin{array}{c}0.059^{* *} \\
(0.028)\end{array}$ & $\begin{array}{c}0.015 \\
(0.030)\end{array}$ & $\begin{array}{c}0.014 \\
(0.030)\end{array}$ & $\begin{array}{l}-0.024 \\
(0.026)\end{array}$ & $\begin{array}{l}0.431^{*} \\
(0.224)\end{array}$ & $\begin{array}{l}-0.027 \\
(0.025)\end{array}$ \\
\hline Time-fixed effects & No & Yes & Yes & Yes & Yes & Yes & Yes & Yes \\
\hline County-fixed effects & No & Yes & Yes & Yes & Yes & Yes & Yes & Yes \\
\hline GRE & No & No & No & Yes & Yes & Yes & Yes & Yes \\
\hline Yields & No & No & No & Yes & Yes & Yes & Yes & Yes \\
\hline Observations & 1389 & 1389 & 1389 & 1358 & 1357 & 1085 & 615 & 742 \\
\hline Number of counties & & 280 & 280 & 277 & 277 & 277 & 127 & 150 \\
\hline
\end{tabular}

Note: The table shows county-level panel estimates. Standard errors in parentheses are clustered at the county level. 13 observations drop out from the analysis because of missing information for the district of Cologne in the 1816 data. Significance: ${ }^{* * *} \mathrm{p}<0.01,{ }^{* *} \mathrm{p}<0.05,{ }^{*} \mathrm{p}<0.1$.

Source: See Cinnirella and Hornung (2016) for data sources and details. 